Landslides (2022) 19:1-5

DOI 10.1007/s10346-021-01820-4

Received: 5 December 2021

Accepted: 7 December 2021

Published online: 5 January 2022

๑) Springer-Verlag GmbH Germany,

part of Springer Nature 2022

\section{Kyoji Sassa \\ The Fifth World Landslide Forum and progress of the open access book series for Kyoto Landslide Commitment 2020}

The Fifth World Landslide Forum (WLF5) was organized on 2-6 November 2021 in Kyoto, Japan. WLF5 was initially planned to be organized on 2-6 November 2020, and the Kyoto Landslide Commitment 2020 was planned to be launched in November 2020. Due to the COVID-19 pandemic, we had to postpone WLF5 by one year to November 2021. However, the launching of the Kyoto Landslide Commitment 2020 (KLC2020) and paper submission for $\mathrm{WLF}_{5}$ proceeded as initially planned. Two thematic issues of Journal "Landslides" titled as "Sendai Landslide Partnerships 2015-2025" were published in October and November 2020. The launching session of the Kyoto Landslide Commitment 2020 was organized on 5 November 2020. After the greeting sessions and panel discussion, the Kyoto Landslide Commitment 2020 was launched by all participants from 90 signatory organizations (Sassa 2021a).

The papers submitted to the six themes of $\mathrm{WLF}_{5}$ were reviewed, revised, accepted and published in six volumes of books, "Understanding and Reducing Landslide Disaster Risk," (Vol.1-Vol.6) in January 2021. Organization of WLF5 progressed during 2021 with hopes of a primarily in-person event. However, the COVID-19 situation around the World and in Japan did not allow the face-to-face conference even in September-October 2021. Then, the Organizing Committee of WLF5 decided to organize the Forum in a hybrid mode (onsite, online-virtual, and pre-recorded modes). This Preface reports the greeting session and the high-level panel discussion "Review of KLC2O2O and the way forward" in the hybrid Fifth World Landslide Forum-Implementing and Monitoring the Sendai Landslide Partnerships 2015-2025 - Voluntary contribution to the Sendai Framework 2015-2025 and the Agenda 2030-Sustainable Development Goals. Other activities including the list of all speakers, countries, and presentation titles in parallel sessions are reported in the category of News/Kyoto Commitment.

\section{Opening greetings of the Fifth World Landslide Forum on 3} November 2021

Figure 1 is the group photo of the onsite participants at the end of high-level panel discussion "Review of KLC2020 and the way forward." Table 1 presents the number of all participants (onsite, online, and pre-recorded) in WLF 5 with a total of 525 persons from 46 countries/regions, three global scientific organizations (IUGG, IUGS, and WFEO), and five United Nations Organizations (FAO, UNDRR, UNESCO, UNU, and WMO). The maximum number of participants are from Japan was 215. Due to COVID-19, no person from foreign countries/regions attended $\mathrm{WLF}_{5}$ in Kyoto, Japan. The large number of participants from other countries/regions is 47 from Italy, 45 from China, 21 from USA, 16 from Czech Republic, and 10 from UK, India, Indonesia, and Chinese Taipei. The number of onsite participants from Japan was 154.

WLF5 started with an Opening Address from the primary organizer. The Under-Secretary-General of the United Nations and the United Nations Special Representative of the Secretary-General for Disaster Risk Reduction addressed greetings to WLF5 attendees. The Secretary General of the World Meteorological Organization (WMO), the Deputy Director-General of the Food and Agriculture Organizations (FAO), Assistant Director-General of the United Nations Educational, Scientific and Cultural Organization (UNESCO), and the President of the World Federation of Engineering Organizations (WFEO) extended the greetings as the ICL supporting organizations. President of the International Union of Geodesy and Geophysics (IUGG) and President of the International Union of Geological Sciences (IUGS) presented their supporting greetings to ICL and WLF5. Those greetings are planned to be published in the founding issue of the open access book series "Progress in Landslide Research and Technology" in 2022. Welcome messages from the host country (Sabo Planning Coordination, Ministry of Land Infrastructure, Transport and Tourism, Japan) and from the host university (Kyoto University) were delivered at the end of this session.

\section{Program of the opening session}

Opening address from the primary organizer

$>$ Nicola Casagli (President of the International Consortium on Landslides)

\section{Greetings from United Nations organizations}

David Malone (Under-Secretary-General of the United Nations/Rector of the United Nations University)

$>$ Mami Mizutori (United Nations Special Representative of the Secretary-General for Disaster Risk Reduction)

$>$ Petteri Taalas (Secretary-General of the World Meteorological Organization: WMO)

$>$ Maria Helena Semedo (Deputy Director-General of the Food and Agriculture Organizations: FAO)

$>$ Shamila Nair-Bedouelle (Assistant Director-General for Natural Sciences, the United Nations Educational, Scientific and Cultural Organization: UNESCO) 


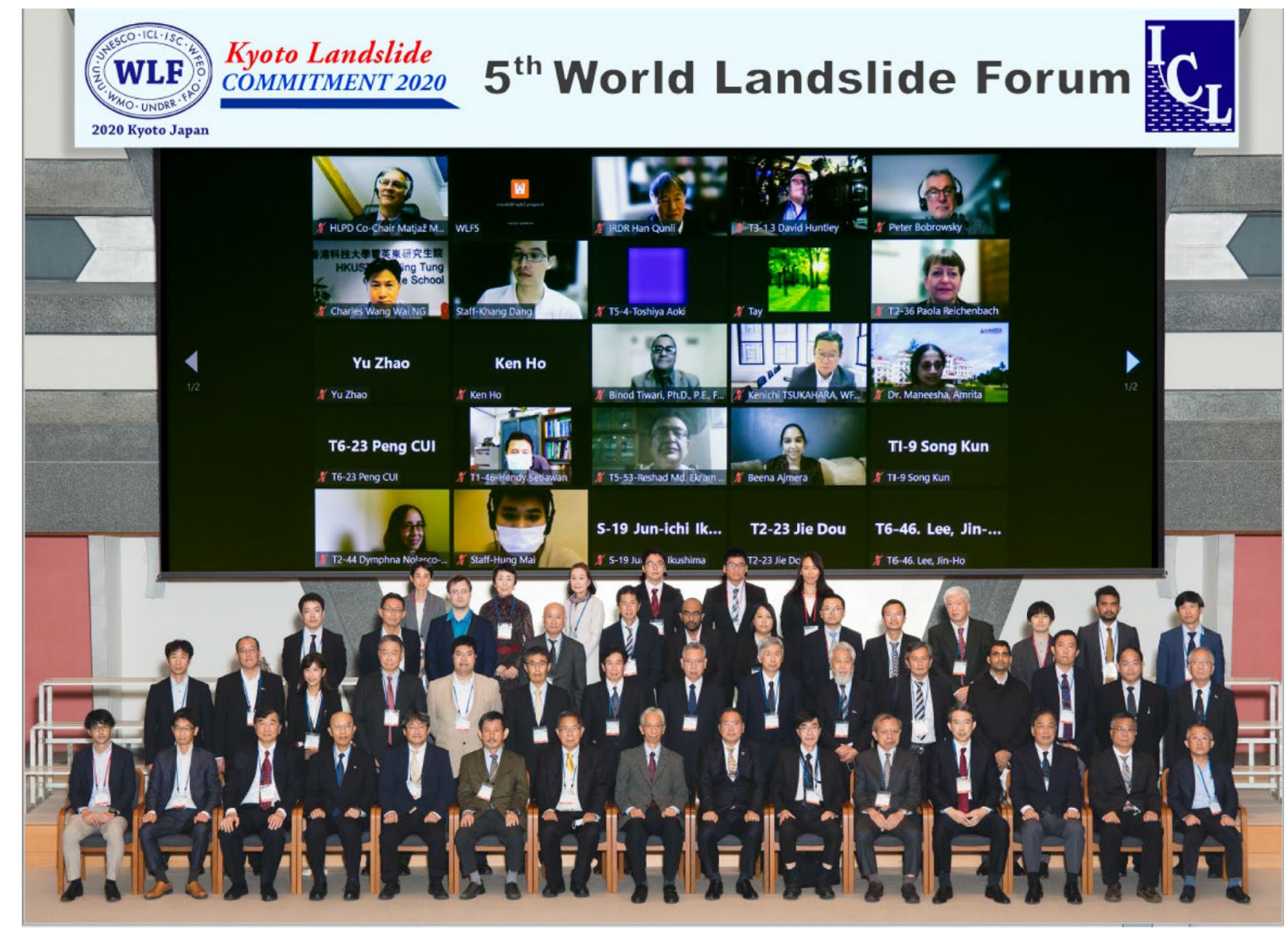

Fig. 1 Group photo of the WLF5 onsite participants in Room A of the Kyoto International Conference Center and on the Online Zoom Platform on 3 November 2021

Greetings from scientific organizations

$>$ José M.P. Vieira (President of the World Federation of Engineering Organizations: WFEO)

$>$ Kathryn Whaler (President of the International Union of Geodesy and Geophysics: IUGG)

$>$ John Ludden (President of the International Union of Geological Sciences: IUGS)

Welcome messages from host organizations

$>$ Hiroaki Tsunakawa, Director for Sabo Planning Coordination, Ministry of Land Infrastructure, Transport and Tourism, Japan

$>$ Akira Murakami, Executive Vice-President of Kyoto University

Prof. Akira Murakami, Executive Vice-President of Kyoto University, came to the Kyoto International Conference Center and presented welcome message on site. He joined this group photo (front and center) in Fig. 1.
High-level panel discussion "Review of KLC2020 and the way forward" on 3 November 2021

The Kyoto 2020 Commitment for Global Promotion of Understanding and Reducing Landslide Disaster Risk (Kyoto Landslide Commitment 2020: KLC2020): A Commitment to the Sendai Landslide Partnerships 2015-2025, the Sendai Framework for Disaster Risk Reduction 2015-2030, the 2030 Agenda Sustainable Development Goals, the New Urban Agenda and the Paris Climate Agreement was launched on 5 November 2020 by the adoption of 2020 Kyoto Declaration at the end of the launching session. One year has passed after the launching of the KLC2020. At the Fifth World Landslide Forum, a high-level panel discussion reviewed the progress of KLC202O and strategized the way forward by inviting panelists from ICL supporting organizations (UNDRR, UNESCO, WFEO, IUGS, and IUGG), three ICL full members, and one ICL supporter.

At the beginning of this session, two forum chairs (Immediate Past-president and Executive Director of the ICL) presented opening greetings. Under the chair from the Global Promotion Committee of IPL and the KLC2020 Secretariat, firstly, Secretary General of 
Table 1 Participants of the Fifth World Landslide Forum

\begin{tabular}{|c|c|c|c|c|c|c|c|}
\hline No & Country/regions & Participants & Percentage & No & Country/regions & Participants & Percentage \\
\hline 1 & Australia & 2 & $0.38 \%$ & 30 & Nigeria & 1 & $0.19 \%$ \\
\hline 2 & Bangladesh & 1 & $0.19 \%$ & 31 & Norway & 9 & $1.71 \%$ \\
\hline 3 & Belgium & 3 & $0.57 \%$ & 32 & Philippines & 1 & $0.19 \%$ \\
\hline 4 & Bhutan & 1 & $0.19 \%$ & 33 & Poland & 2 & $0.38 \%$ \\
\hline 5 & Brazil & 2 & $0.38 \%$ & 34 & Republic of Korea & 7 & $1.33 \%$ \\
\hline 6 & Canada & 7 & $1.33 \%$ & 35 & Romania & 1 & $0.19 \%$ \\
\hline 7 & Chile & 3 & $0.57 \%$ & 36 & Russia & 8 & $1.52 \%$ \\
\hline 8 & China & 45 & $8.57 \%$ & 37 & Serbia & 2 & $0.38 \%$ \\
\hline 9 & Colombia & 2 & $0.38 \%$ & 38 & Slovenia & 9 & $1.71 \%$ \\
\hline 10 & Croatia & 3 & $0.57 \%$ & 39 & Spain & 3 & $0.57 \%$ \\
\hline 11 & Czech Republic & 16 & $3.05 \%$ & 40 & Sri Lanka & 2 & $0.38 \%$ \\
\hline 12 & El Salvador & 2 & $0.38 \%$ & 41 & Switzerland & 4 & $0.76 \%$ \\
\hline 13 & Ethiopia & 1 & $0.19 \%$ & 42 & Chinese Taipei & 10 & $1.90 \%$ \\
\hline 14 & France & 3 & $0.57 \%$ & 43 & Turkey & 2 & $0.38 \%$ \\
\hline 15 & Germany & 7 & $1.33 \%$ & 44 & UK & 10 & $1.90 \%$ \\
\hline 16 & Greece & 3 & $0.57 \%$ & 45 & USA & 21 & $4.00 \%$ \\
\hline 17 & Honduras & 2 & $0.38 \%$ & 46 & Vietnam & 4 & $0.76 \%$ \\
\hline 18 & India & 10 & $1.90 \%$ & & & & \\
\hline 19 & Indonesia & 10 & $1.90 \%$ & & \multicolumn{3}{|c|}{ International Organizations } \\
\hline 20 & IRAN & 1 & $0.19 \%$ & & IUGG & 2 & $0.38 \%$ \\
\hline 21 & Italy & 47 & $8.95 \%$ & & IUGS & 2 & $0.38 \%$ \\
\hline 22 & Japan & 215 & $40.95 \%$ & & WFEO & 1 & $0.19 \%$ \\
\hline 23 & Malaysia & 5 & $0.95 \%$ & & \multicolumn{3}{|c|}{ United Nations organizations } \\
\hline 24 & Mauritius & 1 & $0.19 \%$ & & FAO & 1 & $0.19 \%$ \\
\hline 25 & Mexico & 6 & $1.14 \%$ & & UNDRR & 3 & $0.57 \%$ \\
\hline 26 & Morocco & 1 & $0.19 \%$ & & UNESCO & 3 & $0.57 \%$ \\
\hline 27 & Nepal & 3 & $0.57 \%$ & & UNU & 1 & $0.19 \%$ \\
\hline 28 & Netherlands & 7 & $1.33 \%$ & & WMO & 1 & $0.19 \%$ \\
\hline 29 & New Zealand & 5 & $0.95 \%$ & & Total & 525 & $100 \%$ \\
\hline
\end{tabular}

KLC2020 secretariat presented a keynote speech "Review of KLC2O2O and a new open access book series for KLC2020." Nine panelists, as described below, presented talks on different aspects. At the end of the panel discussion, Satoru Nishikawa (Nagoya University) from the floor addressed the significance of this new open access book as a platform for practitioners and proposed to organize a side event in the coming Global Platform for Disaster Risk Reduction in Bali, May 2022.
Sálvano Briceño (First Chairperson of the Global Promotion Committee of IPL (2007-2014), Former Director of UNISDR (Director of UNISDR in 2001-2011)) addressed the concluding remarks and stressed the significance of an intergovernmental cooperation framework on landslide risk reduction, hopefully to be incorporated into the Intergovernmental Panel on Climate Change. 
An explanation to IPL, KLC2020, and the new Global Promotion Committee of the IPL and KLC2020

The Tokyo Action Plan was adopted at the United Nations University in January 2006. To promote the International Program on Landslides (IPL) along the Tokyo Action Plan, ICL exchanged a memorandum of understanding (MoU) with each of ICL supporting organizations of UNESCO, UNDRR (UNISDR), WMO, FAO, UNU, ISC (ICSU), and WFEO in 2006. An IPL logo (Fig. 2) including those organizations was agreed upon. The Global Promotion Committee of the IPL was established to manage the IPL with Sálvano Briceño (Director of UNISDR in 2001-2011) as the first chair of the committee. Following the launching of the Kyoto Landslide Commitment 2020 on 5 November 2020 and the launching of the open access book series for KLC2O2O as a result of the high-level panel discussion on 3 November 2021, the Global Promotion Committee of the IPL has decided, on 26 November 2021, to extend it to manage the IPL and KLC2020, namely, the Global Promotion Committee of the International Program on Landslides and the Kyoto Landslide Commitment 2020 (IPL-KLC Global Promotion Committee). The logo of this committee is shown in Fig. 2.

Program of the high-level panel discussion

Opening Greetings from Forum Chairs

Peter Bobrowsky (Geological Survey of Canada, Canada)

Kaoru Takara (Kyoto University, Japan)

Chairs: Matjaž Mikoš (Co-Chair, Global Promotion Committee of IPL / Chair of WLF4, Ljubljana, 2017)

Kazuo Konagai (Chair of Science Committee of the KLC2020 Secretariat, Kyoto, Japan)

Opening Speeches from chairs

Keynote speech

$>$ Kyoji Sassa (Secretary General of KLC2020 Secretariat): review of KLC2O2O and a new open access book series for KLC2O2O

Speeches from nine panelists from KLC2020 signatory organizations

\section{ICL supporting organizations}

$>$ Paola Albrito (Chief of Branch, Intergovernmental processes, Interagency cooperation and Partnerships, UNDRR)

$>$ Soichiro Yasukawa (Programme Specialist on Disaster Risk Reduction, UNESCO)

$>$ José M.P. Vieira (President of the World Federation of Engineering Organizations: WFEO)

$>$ Hiroshi Kitazato (Treasure of IUGS, Tokyo University of Marine Science and Technology, Japan)

Fig. 2 Logo of the IPL-KLC Global Promotion Committee: IPL logo including the ICL supporting organizations (left side) and the logo of the Kyoto Landslide Commitment 2020 coming from IPL (right side)
$>$ John LaBrecque (Chair of IUGG GeoRisk Commission, Center for Space Research, University of Texas Austin, USA)

\section{ICL full members}

$>$ Binod Tiwari (Vice President for America, California State University, Fullerton, USA)

$>$ Paola Reichenbach (Director of Research, IRPI, Italian National Research Council, Italy)

$>$ Maneesha Ramesh (Dean, School for Sustainable Development and International Programs, Amrita University, India)

\section{ICL supporter}

$>$ Hiroaki Tauchi (General Manager, International Geohazard Management Department, Nippon Koei, Co., Ltd., Tokyo, Japan)

\section{Discussion (panelists and floor)}

Concluding remarks

$>$ Sálvano Briceño (First Chairperson of the Global Promotion Committee of IPL (2007-2014), Former Director of UNISDR (2001-2011)

Adoption of the launching declaration of the ICL open access book series for KLC2020

Kyoji Sassa explained the launching declaration of the ICL open access book series for KLC2020. All panelists and participants on the floor and online agreed to the adoption of the launching declaration below. Thus, the new open access book series "Progress in Landslide Research and Technology" was launched on 3 November 2021.

\section{Launching Declaration of the ICL Open Access Book Series "Progress in Landslide Research and Technology" for the Kyoto Landslide Commitment 2020}

The Kyoto 2020 Commitment for Global Promotion of Understanding and Reducing Landslide Disaster Risk (Kyoto Landslide Commitment 2020) -A Commitment to the Sendai Landslide Partnerships 2015-2025, the Sendai Framework for Disaster Risk Reduction 2015--2030, the 2030 Agenda Sustainable Development Goals, the New Urban Agenda, and the Paris Climate Agreement was launched on 5 November 2020 together with 90 signatories. The KLC2020 established a Secretariat of the Kyoto

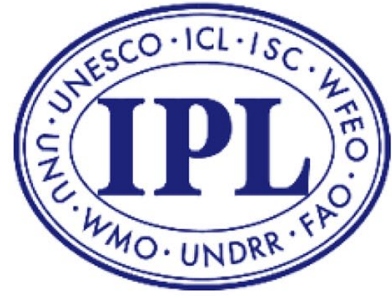

Kyoto Landslide COMMITMENT 2020 
Landslide Commitment within the ICL Secretariat in Kyoto, Japan at the same time.

In order to promote "Kyoto 2020 Commitment until 2030 and beyond," a new stable and global platform is essential for the information dissemination and collaboration within KLC2O2O partners and the Society. Therefore, the establishment of an Open Access book series of the International Consortium on Landslides (ICL) "Progress in Landslide Research and Technology" was planned and proposed by the KLC2020 Secretariat. This book series can be downloaded free of charge by all, both in developing and developed countries suffering from landslide disasters and also the policy- makers involved in landslide disaster risk reduction.

Until today, twenty international/national and public/private organizations in the world have accepted the role of the KLC2O20 official promoters who promote the Kyoto Landslide Commitment 2020 and provide financial support for the implementation of the KLC2O2O activities. Many experts have accepted the role of voluntary editors and advisory members. Both financial and personal resources have been secured for this new publication series.

On 3 November 2021 during the Fifth World Landslide Forum in Kyoto, Japan, at the high-level panel discussion "Review of KLC2O2O and the way forward,", all panelists and participants agreed on, and declared the launching of the ICL Open Access Book Series "Progress in Landslide Research and Technology" for the Kyoto Landslide Commitment 2020

Date: 3 November 2021 Place: Kyoto, Japan

The open access book series for KLC2020

The KLC2020 Secretariat provided a preliminary examination of the new open access book series "Progress in Landslide Research and Technology (P-LRT)" and published the associated details online on October 7, 2021 (Sassa 2021b). This concept was supported by many colleagues around the world. The book series was formally launched on 3 November 2021. The open access book P-LRT is published by the Secretariat of the Kyoto Landslide Commitment 2020, which is hosted by the Secretariat of the ICL, Kyoto, Japan. The secretariat globally called for financial and editorial supports to the KLC2020. So far, twenty KLC2020 official promoters (public and private organizations) have agreed to offer financial support to promote the Kyoto Landslide Commitment 2020 , and 27 editors have agreed to work voluntarily for this book series. The KLC2020 Secretariat is currently calling for articles in the founding issues of P-LRT in 2022 as follows.

Call for articles in the founding issues of ICL open access book series "Progress in Landslide Research and Technology" Deadline of manuscript submission: 28 February 2022 (Vol.1, No.1) and 30 June 2022 (Vol.1, No.2).

Publication Springer-Nature for digital and print issues Sub-title of the founding issues (Vol.1, No.1 and No.2): KLC2020 and 5th World Landslide Forum.

Open access Digital including active link to video. Print version is charged.
Format Same as books of WLF5

Contents Original articles targeted for Practice and Society

Categories (1) Original articles, (2) Review articles, (3) IPL/WCoE/ KLC2O2O, (4) Teaching Tools, (5) Technical note/Case studies, (6) World Landslide Reports, (7) KLC2020 official promoters

- Each oral speaker of WLF5 is invited to present an article describing progress in landslide research and technology for practical applications and the benefit to the society (8-10 pages). The article may be accompanied with a video (6-10 pages).

- Each Session Convener of WLF5 is invited to report his/her session with a short introduction of session speakers, including the recorded video (optional): 10-15 pages.

- Regular articles on "Progress in Landslide Research and Technology" (Categories 1-7)

- Book Processing Charge (BPC) is US\$50/page. BPC is reduced for ICL members and KLC2020 official promoters in the founding issues.

\section{Steps from submission to publication for Vol. 1, No. 1/No.2}

1. Submission of manuscript to the Online Conference Service (OCS): by 28 February 2022/30 June 2022

2. Screening editors will inform authors: (1) accept to in-depth review or (2) revise before in-depth review within 10 days after submission

3. Payment of Book Processing Charge (BPC) with credit card

4. In-depth review and revision

5. Publication by Springer: July 2022/ November 2022

The Secretariat of the KLC2020 calls for support to this new initiative of the Kyoto Landslide Commitment 2020 and contributions to this new open access book series for the global promotion of landslide disaster risk reduction for the benefit of the society.

Inquiries regarding the new open access book series "Progress in Landslide Research and Technology," and offer of cooperation supporting the Kyoto Landslide Commitment 2020 can be addressed to:

\section{Secretariat of the Kyoto Landslide Commitment 2020}

International Consortium on Landslides

138-1 Tanaka-Asukai cho, Sakyo-ku, Kyoto 606-8226, Japan

Email: klc202o@iclhq.org

\section{References}

Sassa K (2021a) The Kyoto Landslide Commitment 2020: Launched. Landslides 18(1):5-20

Sassa K (2021b) New open access book series Progress in Landslide Research and Technology. Landslides 18(11):3509-3512

Kyoji Sassa $(\bowtie)$

International Consortium on Landslides, Kyoto, Japan

Email: sassa@iclhq.org 